\title{
Online Marketing Communication in the Tourism Industry: An Exploratory Study of Website Effectiveness Among Tourist Lodge Operators in Northern Ontario
}

\author{
Ron Mulholland, School of Commerce, Laurentian University \\ Jean-Charles Cachon, School of Commerce, Laurentian University
}

ABSTRACT. The use of the Internet for marketing communication was studied in a sample of 200 lodge operators from Northern Ontario. These firms are located in remote areas relative to their United States-based clientele. The use of the Internet for marketing communications was perceived as important to keep existing clients and secure new ones. Results show a correlation between levels of website expenses and levels of responsiveness from prospective clients. There is an indication that investing more money and time in a website can improve customer-base diversification.

SOMMAIRE. Nous avons étudié l'utilisation de l'Internet pour la communication commerciale par l'intermédiaire d'un échantillon de 200 hôteliers du nord de l'Ontario. Ces entreprises sont situées dans des régions éloignées de leur clientèle américaine. L'utilisation de l'Internet pour la communication commerciale est considérée importante pour conserver la clientèle existante et pour en acquérir une nouvelle. Nos résultats montrent une corrélation entre le niveau des dépenses Web et le niveau de réponse de clients éventuels. Il semble qu'investir davantage d'argent et de temps dans un site Web puisse accroître la diversification de la clientèle.

\section{Introduction}

Growth in consumer use of the Internet makes it a viable marketing communication channel through which firms can effectively reach a broad audience. Recent statistics indicate that online travel sales increased $61 \%$ between 2001 and 2002 in Europe and $45 \%$ in the U.S. (where the overall travel market decreased by $8 \%$ in 2001 , and $4 \%$ in 2002); while consumers purchased five per cent of the products of the American travel industry on the Net in 2000, online sales accounted for $14.4 \%$ of the total in 2002 (Marcussen, 2003). As the Internet becomes more and more easily accessed (by 2002, $49 \%$ of connected Canadian households had a highspeed connection-Veenhof, Neogi and van Tol, 2003), consumer goods and services advertisers are increasing their use of the Internet for marketing communications. Over $50 \%$ of business respondents to a Forrester Research survey indicated online media would constitute the highest percentage of their media budget. Internet marketing communication is attractive to the tourism industry as "travel is an information-based product and the Internet is full of information." (Connolly, Olsen, and Moore, 1998)

The Internet places all tourist establishments on an equal footing in terms of marketing communications. A remote resort or tourist lodge with radiotelephone and difficult physical access is no longer at a disadvantage from a promotional perspective. The Internet provides timely, high quality, interactive communication with 
potential consumers, facilitating diversification and growth of clientele for all firms willing to expose themselves on the Internet (Turban, Lee, King, and Chung, 2000). According to Statistics Canada (2001) $66 \%$ of tourism businesses, as represented by the accommodation and food services sector, utilized computers, $32 \%$ are making use of the Internet and $17.4 \%$ have a website. This study is an exploratory glimpse at how tourist lodge operators, throughout Northern Ontario, have incorporated a website as part of their marketing communications, the time and resources they invested, and the benefits they realized from it.

\section{Literature Review}

\section{Marketing Communications and the Internet}

Marketing communications describes all activities a company undertakes to let consumers know about their products. Specific objectives for marketing communications might include: "to provide information, to increase demand, to differentiate the product ... to produce sales" (Beckman and Rigby, 2003).

The online consumer has been modeled by Hoffman and Novak (1996). Most consumers seek product or service information, while some are goal directed, others seek only the experience of navigation. They identify the Internet as an interactive environment in which consumers can be engrossed in a state of "flow." Potential for interaction with consumers is "unprecedented," business growth potential resulting is high.

The Internet has been identified as cost effective and easier to set-up and update than traditional marketing communication channels (Morgan, 1996). Marketing communications on the Internet have four stages of complexity from a simple website with no interactivity, to a website with email interactivity, website with offline transactions, to a complex site with online transactions, complete interactivity and distribution (Van Doren, Fechner, and Green-Adelsberger, 2000).

\section{Information on the Internet}

Information is a necessity to the traveler. Tourists need information to aid planning before they embark on a trip or purchase a vacation. As no refund is typically available for bad service, or a bad vacation, consumers face a significant risk. O'Connor (1999) points out that "since travelers cannot pre-test the product or easily get their money back if the trip does not meet up to their expectations, access to accurate, reliable, timely, and relevant information is essential to help them make an appropriate choice."

Because of the inability to pre-test or preview the tourism service, marketing communications is a key factor in consumer choice, much more so than in other more tangible consumer products or services. Buhalis and Main (1996) acknowledge "the greater the degree of perceived risk in a pre-purchase context, the greater the consumer propensity to seek information about the product." Tourists seek current reliable information and may make a high-risk decision about their vacation destination based on this information.

Tourist lodge operators traditionally used print-based media such as brochures, flyers, and magazine advertisements, or direct contact with consumers at tourism trade shows for marketing communications. These conventional channels of communication are expensive, time consuming, and labor intensive for the operator. 
The appearance on the Internet of the World Wide Web (Web) presents an opportunity for the operator to deliver timely, and accurate, information to a large potential audience, at a relatively lesser cost. Many vacation lodgings operators recognize the Web as a potentially powerful marketing tool (Van Hoof and Combrink, 1998). Cachon and Cotton (1997) found a sub-sample of business owners from the tourism industry significantly more convinced of the usefulness of the Web than their counterparts from other sectors (the study took place in a popular tourist area of Northern Ontario). The question is, to what extent have the results of this migration to the Web for marketing communication been quantified? Does making tourism information available on the Web have an impact on tourist business performance?

\section{Travel Market Size}

To give the Internet travel market size and growth some context, the U.S. online travel market totaled $\$ 7$ billion in 1999 , and was projected to reach $\$ 18.6$ billion in 2001, and $\$ 27$ billion in 2002 (PhoCusWright Yearbook, 1999 and 2000). Travel sales from all sources were $\$ 187.5$ billion in 2002 . Most hotels expected the Internet to represent about $10 \%$ of total bookings by 2004 (PhoCusWright Yearbook, 1999).

The dollar value of the Northern Ontario tourism market is approximately $\$ 1.3$ billion. This represents $8.1 \%$ of the Ontario market, which totals $\$ 16.5$ billion annually. Visitors to Northern Ontario number 9.4 million or $8.9 \%$ of the Ontario visitor total (Statistics Canada, 2001).

The number of visitors and dollar value of the Northern Ontario tourism market is important to tourist lodge operators. Successfully attracting customers is a key to maintaining and growing one's business and an ongoing challenge. Internet marketing communication may be a cost effective alternative to conventional channels of communication.

\section{Potential Costs of Internet Marketing}

The amount of money spent establishing a website varies greatly. It is possible to spend a few hundred dollars or many thousand. "Such high investment costs require justification and payback analysis, but it is difficult to measure potential returns since not all shoppers use the Internet for the actual purchase of a product or service even though information ascertained on the Web may have been the influencing factor" (Connolly, Olsen and Moore, 1998b).

Another real cost is the time required for maintenance of the website and response to email inquiries. According to the Dotcom Survival Guide (2000), ebusinesses are urged to "update your site frequently to encourage repeat traffic. If your customers anticipate that they will find something new on a regular basis, they will visit (and buy) more often." Lodge operation is a time-intensive service business; any activity such as site updating, which requires labor hours, takes away from resources necessary for the service provision of the core product. Businesses which are seasonal may use off-peak times for website maintenance just as they do physical maintenance, although many lodges are year-round operations as snowmobile tourism is popular in this region. The question is how much time are operators spending on website maintenance? 


\section{Potential Benefits of Internet Marketing}

The value in utilizing the Internet for marketing can start with cost reductions as Mougayar (1998) points out:

Basic cost reductions might start with publishing costs, which include the cost of producing, printing and distributing information for customers or employees. Another area involves looking at the buying/selling model and measuring cost reduction associated with each step of the process, such as general marketing, selling, and support costs.

Diversification of customer base and ability to market outside the region and country are part of the value. Lituchy and Rail (2000) found the ability to expand the customer base from both inside and outside the country as a major reason for having a website.

A key to this diversification is converting website viewers into customers. It is important that viewers are able to place further inquiries by email or telephone, allowing the establishment operator an opportunity to convert them into a customer (Stergiou and Airey, 2003).

\section{Web Marketing Results}

As Connolly, Olsen and Moore (1998a) point out, "we know travelers are using the Internet to shop for travel, the degree to which the Internet truly influences travel-purchase decisions remains less certain."

The present study explores lodge owners' experience with their website, the traffic on the website, and email traffic. It presents some objective results of having a website, as well as the owners' assessment of the success and importance of a website.

\section{Model}

The model illustrated in Figure 1 follows from a review of the literature which links website development and use to increased economic performance by a firm through the number of website hits and emails, the conversion rate of email inquiries (that is, the percentage of email inquiries turned into bookings), and the



Figure 1. A model of website inputs and results for tourism lodge operators 
diversification of customer base. In the model, signs above the arrows indicate the expected relationship between variables.

A number of hypotheses are implied by the model: it suggests that input (independent) variables including the initial investment, maintenance costs and time spent on maintenance and email response will be positively correlated with the number of website hits, emails, diversification of market sources and conversion rate of visitors. These will in turn be correlated with increased sales.

\section{Method}

A telephone survey of 330 tourist lodge operators listed in the Northern Ontario Tourist Outfitters (NOTO) registry took place during a two-week period in the summer of 2000 . To qualify for the survey, the lodge had to have a website listed. This group represented over half of the 600 members of NOTO. In total, 200 tourist lodge owners responded. The survey included 22 questions and investigated such issues as website development, maintenance, and traffic, the impact of the website on the business, email usage, conversion rates, and also some descriptive questions about the respondents.

All respondents were either owners or managers of the operation. Most respondents had operated their websites for two to three years (mean of 2.68, standard deviation of 1.50 ), though they ranged from less than a month to eight years. Further results follow.

\section{Results}

The first step in data analysis was to construct a table of variable average responses to the questions (Table 1). A typical company had a contractor developed website in place for almost three years. Monthly costs were in the $\$ 40-\$ 50$ range. Operators spent a small amount of time on website maintenance (1.4 hours/month average) while responding to emails required 19 hours per month.

T-tests were conducted using one of three dichotomous variables to group the data. For example, $66 \%$ of respondents reported their customer base had become more diversified. A one-tailed t-test indicated this group spent significantly more money $(\mathrm{p}<.03)$ on initial website creation than did the group (34\% of respondents) who found no increased diversification. A further t-test found that this group also spent significantly more money on monthly website hosting than the group who found no diversification in customer base.

A t-test was carried out to determine if the group of $76 \%$ of respondents who reported sales increase differed from those who did not report sales increase on initial website expense, or monthly expense or if those who paid a contractor to develop the website had more hits or emails. Details are found in Table 2.

The table indicates that those operators who spent more on website creation on average felt that their customer base had become more diversified. Additionally those that spent more money on website hosting felt that their customer base had become more diversified. There was no difference found for those who noticed a sales increase and those who did not. Additionally, the average number of website hits and emails did not significantly differ between those whose website was selfcreated or contracted.

The next step was to further investigate the relationships between ratio variables. The model indicates a potential relationship between website inputs and 


\begin{tabular}{|c|c|c|}
\hline$n=200$ & $\begin{array}{l}\text { Variable Average } \\
\text { Value }\end{array}$ & $\begin{array}{l}\text { Standard } \\
\text { Deviation }\end{array}$ \\
\hline Average number of years the company had a website & 2.7 & 1.5 \\
\hline A verage number of website hits per month & 380 & 372 \\
\hline \multirow{2}{*}{$\begin{array}{l}\text { Average number of monthly emails } \\
\text { Percent of respondent websites developed by outside contractors }\end{array}$} & 199 & 294 \\
\hline & $83 \%$ & $\ldots$ \\
\hline Average cost of developing the website & $\$ 836$ & 941 \\
\hline Average cost of monthly hosting & $\$ 44$ & 57 \\
\hline \multicolumn{3}{|l|}{ Average number of monthly hours spent on website maintenance } \\
\hline \multicolumn{3}{|l|}{ Average number of monthly hours spent on responding to email queries } \\
\hline & 19 & 17 \\
\hline \multicolumn{3}{|l|}{ Percentage of respondents reporting a reduction in print advertising expense } \\
\hline \multirow{2}{*}{\multicolumn{3}{|c|}{ Percentage of average print advertising budget represented by this reduction }} \\
\hline & & \\
\hline $\begin{array}{l}\text { Percentage of respondents who estimate a reduction in the number of } \\
\text { telephone inquiries }\end{array}$ & $33 \%$ & - \\
\hline Percentage of Internet inquiries converted to bookings & $19 \%$ & - \\
\hline $\begin{array}{l}\text { Percentage of respondents who report increased sales as a result of being on } \\
\text { the Internet }\end{array}$ & $76 \%$ & - \\
\hline $\begin{array}{l}\text { Average percentage increase in sales reported as a result of being on the } \\
\text { Internet }\end{array}$ & $8.8 \%$ & - \\
\hline $\begin{array}{l}\text { Percentage of respondents who report a diversification in customer base as a } \\
\text { result of being on the Internet }\end{array}$ & $66 \%$ & - \\
\hline Respondent average percentage of customers from Ontario & $22 \%$ & - \\
\hline Average percentage of customers from Canada excluding Ontario & $3.5 \%$ & - \\
\hline Average percentage of customers from outside Canada (mainly U.S.) & $74 \%$ & - \\
\hline Percentage of respondents who use a radiotelephone (no land line available) & $36 \%$ & - \\
\hline $\begin{array}{l}\text { Percent of respondents who pay long distance charges for an Internet } \\
\text { connection } \\
\text { Average rating }(1-10 \text { scale-no importance to great importance) of }\end{array}$ & $22 \%$ & - \\
\hline $\begin{array}{l}\text { Average rating ( } l-10 \text { scale-no importance to great importance) of } \\
\text { importance of having a Web page }\end{array}$ & 7.4 & 1.5 \\
\hline
\end{tabular}

Table 2: T-tests of Variable Groups
Variable
Average cost of developing the website
Cost of monthly hosting
Average cost of developing the website
Cost of monthly hosting
Average number of website hits per
month
Average number of monthly emails

\begin{tabular}{lccc}
\hline \multicolumn{1}{c}{ Groups } & $\begin{array}{c}\text { Group } \\
\text { Means }\end{array}$ & \multicolumn{1}{c}{$\begin{array}{c}\text { Sig. } \\
\text { One-tailed }\end{array}$} \\
\hline $\begin{array}{l}\text { customer base diversified } \\
\text { customer base not div. }\end{array}$ & $\$ 923$ & -1.85 & 0.03 \\
customer base diversified & $\$ 652$ & & \\
customer base not div. & $\$ 58$ & -2.17 & 0.02 \\
sales increased & $\$ 29$ & & \\
$\begin{array}{l}\text { sales not increased } \\
\text { sales increased }\end{array}$ & $\$ 850$ & 0.02 & 0.49 \\
$\begin{array}{l}\text { sales not increased } \\
\text { website self-created }\end{array}$ & $\$ 553$ & -0.72 & 0.24 \\
website contractor created & $\$ 40$ & & \\
website self-created & 357 & 0.32 & 0.37 \\
website contractor created & 171 & 0.54 & 0.29 \\
\hline
\end{tabular}

results. Inputs include such attributes as the amount spent on developing the website; whether it was developed by a contractor; and time and money spent on maintenance and email response. Website results include tangible items such as the number of hits, number of emails as well as respondent estimates and reports of conversion rate from inquiries, diversification of market sources and attributed sales increases. A correlation analysis between ratio variables reveals a number of significant relationships as illustrated in Table 3. 


\begin{tabular}{|c|c|c|c|c|c|c|c|c|c|c|c|c|c|c|c|}
\hline 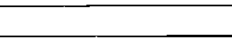 & 1 & 2 & 3 & 4 & 5 & 6 & 7 & 8 & 9 & 10 & 11 & 12 & 13 & 14 & 15 \\
\hline \multicolumn{16}{|l|}{ Website Inputs } \\
\hline 1. Years with website & & & & & & & & & & & & & & & \\
\hline $\begin{array}{l}\text { 2. Initial website } \\
\text { expense }\end{array}$ & $.347 * *$ & 1 & & & & & & & & & & & & & \\
\hline $\begin{array}{l}\text { 3. Monthly website } \\
\text { 3onse }\end{array}$ & $.195 * *$ & $.239 * *$ & l & & & & & & & & & & & & \\
\hline $\begin{array}{l}\text { expense } \\
\text { 4. Hrs/mth }\end{array}$ & $.196^{* *}$ & -0.112 & 0.059 & 1 & & & & & & & & & & & \\
\hline maintaining website & & & & & & & & & & & & & & & \\
\hline $\begin{array}{l}\text { 5. Hrs/mth answering } \\
\text { email }\end{array}$ & $.228 * *$ & $.275^{* *}$ & $.227^{* *}$ & 0.13 & 1 & & & & & & & & & & \\
\hline \multicolumn{16}{|l|}{ Resultant Variables } \\
\hline 6. Website hts/mth & $.218^{*}$ & $.357 * *$ & 0.084 & -0.08 & $.190^{*}$ & & & & & & & & & & \\
\hline 7. Emails/mth & 0.112 & $.156^{*}$ & -0.005 & -0.07 & $.343^{* *}$ & $.300^{* *}$ & 1 & & & & & & & & \\
\hline 8. Print advertising & $.241^{* *}$ & $.228 * *$ & 0.077 & 0.026 & 0.131 & $.186^{*}$ & 0.053 & 1 & & & & & & & \\
\hline 9. \% of email inquiry & $-.143^{*}$ & 0.074 & 0.017 & 0.005 & 0.107 & 0.139 & 0.046 & 0.07 & 1 & & & & & & \\
\hline $\begin{array}{l}\text { conversions } \\
10 . \% \text { of sales }\end{array}$ & 0.059 & 0.085 & 0.151 & $.205^{*}$ & 0.094 & 0.019 & -0.033 & $.317 * *$ & $.434 * *$ & 1 & & & & & \\
\hline $\begin{array}{l}\text { increase resulting } \\
11 . \% \text { of guests from }\end{array}$ &. $.175^{*}$ & 0.01 & -0.073 & -0.029 & -0.017 & 0.126 & 0.05 & -0.026 & $.182^{*}$ & 0.111 & 1 & & & & \\
\hline $\begin{array}{l}\text { Northern Ontario } \\
12 . \% \text { of guests from }\end{array}$ & -0.132 & $-.229^{* *}$ & -0.12 & 0.001 & -0.045 & -0.086 & -0.059 & -0.011 & $.238^{* *}$ & 0.133 & 0.119 & 1 & & & \\
\hline $\begin{array}{l}\text { Southern Ontario } \\
13 . \% \text { of guests from }\end{array}$ & -0.046 & -0.015 & -0.086 & -0.012 & -0.021 & 0.131 & 0.023 & 0.037 & $.156^{*}$ & 0.146 & $.173^{*}$ & -0.02 & 1 & & \\
\hline $\begin{array}{l}\text { Canada } \\
14 . \% \text { of guests from }\end{array}$ & $.169^{*}$ & $.185^{*}$ & $.155^{*}$ & 0.015 & 0.059 & 0.027 & 0.05 & 0.029 & $-.310^{* *}$ & $-.183^{*}$ & $-.468^{* *}$ & $-874^{* *}$ & $-325 * *$ & 1 & \\
\hline $\begin{array}{l}\text { outside Canada } \\
15 \text {. Importance of } \\
\text { having a website }\end{array}$ & $.192^{*}$ & 0.181 & 0.105 & 0.078 & -0.073 & -0.082 & $-.231^{*}$ & $.311^{* *}$ & $.350^{* *}$ & $.442^{* *}$ & -0.023 & -0.131 & 0.135 & 0.04 & 1 \\
\hline
\end{tabular}


The model contemplates a number of outcomes resultant from website inputs. In terms of traffic results for the website, the number of website hits significantly correlated to set-up expense. The length of time a company had a website also significantly correlated to the number of hits. Following on this, the number of emails received per month significantly correlated to the expense in setting up the website and the number of website hits per month. A negative correlation existed between the length of time a company had a website and the number of email inquiries which turn into bookings.

Respondents were hesitant to provide the dollar value of increased sales, however they did indicate increase in percentage of sales. Percentage sales increase correlated with hours per month maintaining the website. A reduction in cost of print advertising also correlated with sales increase as did the percentage of email conversions.

The results show a significant positive correlation between the length of time firms had a website and a number of variables including hits per month on the site, expense to create the site, monthly expense for hosting the site, number of hours responding to emails and savings on print advertising. Additionally a negative correlation with local customers but positive correlation with customers from outside of the country may indicate owners with local customers do not feel the need to have a website. Finally the longer the operator had a website the more it was valued as important for the business.

\section{Discussion}

There is some support for the relationships in the proposed model. The websites observed are the simplest and include email interaction, the second stage in the Van Doren, Fechner and Green-Adelsberger model. There is some support for the Lituchy and Rail (2000) concept of expanding customer-based from outside the country. Presently there is not much to comment on the conversion rate for website viewers into customers (Stergiou and Airey, 2003).

Some preliminary findings of interest include advertising cost reductions correlated with website expense and years of operation. Website hit rate was correlated with years of website operation and initial website expense as was the percentage of guests from outside Canada. Sales increases correlated with hours per month maintaining the website. One must be careful not to infer causation as the direction of relationships is unknown and needs further investigation with more sophisticated methods.

The lodge owners in the present study manage relatively small operations. The average initial investment is relatively small for the website at less than $\$ 1,000$. Website traffic is not heavy with approximately 13 hits and seven emails per day on average.

The majority of clients for these lodge owners are from the U.S., giving an indication that there is substantial physical separation between client and tourist operators. This perhaps explains why these lodges have adopted websites. It would be interesting in the future to survey lodges still without websites to determine whether the client base is similar or perhaps less geographically removed. Another indication of remoteness is that $36 \%$ of lodges use radiotelephones, no telephone lines being available up to their location.

The Internet is a new form of communication for lodge property owners as 
indicated by the average short time that operators have possessed a website. Although tourist lodge operators in the present study seem to have made a relatively small investment, monetary and physical resources for the development and maintenance of a website are likely scarce in their operation. Once a website has been developed and is operating, the results are uncertain, however the costs and time to support it are ongoing. A full 19 hours per month is necessary to respond to email and support the site as well as $\$ 500$ per year to maintain the site. What results accrue to owners?

The results seem to be promising in terms of customer response. It seems that the more operators spend on developing a website initially and hosting it, the more hits it will have. This would indicate that it is worthwhile to invest in website developinent. Additionally, those operators who spent more reported a wider diversification of their customer base as a result of their presence on the Internet, as compared to those who spent less.

There seems to be no penalty for developing your own website if you have the know-how. The absence of a significant difference in hits or emails between selfcreated and externally created websites suggests that the minority $(17 \%)$ of lodge owners who developed their own site is as successful as the others in securing hits and emails. However, the time taken to develop the website is likely to distract these owners from other tasks.

The number of emails received is also correlated to the amount of initial investment as well as the number of hits on the site. The message to operators seems to be that an investment in website development will have positive results in communicating with prospective clients.

A puzzling result is the negative correlation between years with a website and email inquiry conversions. It may be that new websites attract new visitors who are trying to make a vacation decision resulting in a relatively high conversion rate. As the website ages there may be some loss of currency or some other factor contributing to a decline in conversion rate. This is an interesting question for future study.

Operators would like to know if there is a direct relationship between website inputs such as cost and time of resources expended on one side, and tangible outcomes such as sales figures on the other side. The present study did not use sales figures but percentage increase in sales, which did not correlate with any of the website input variables, save for the number of hours per month in maintaining the website. This seems to indicate that there is value in maintaining an up-to-date and attractive website; it may result in new clients to the operation.

Those lodge operators with a website chose to reduce their print advertising expenses significantly, as indicated in the strong correlation between age of the website, initial website expense, and print advertising savings. The reduction in print advertising represented on average nearly a third of the advertising budget. Given that $76 \%$ reported a sales increase as a result of being on the Internet, this reduction in print advertising did not seem to be detrimental to business.

Finally, the operators felt that having a website was important to their business with an average rating of 7.4 on a 10-point scale. This result is significantly higher than the 5.4 rating observed by the Cachon and Cotton (1997) study. 


\section{Conclusions and Implications for Further Research}

Internet marketing communications is a relatively new phenomenon. Although it requires a commitment of scarce monetary and time resources by operators, it has the potential to diversify the client base and result in increased sales. The tourism industry comprises businesses supplying goods and services to travelers, including accommodation, transportation, food and beverages, and related products such as souvenirs, arts and crafts, attractions, travel management, events, conferences, adventure tourism, ecological tourism, and tourism services. The present study is an exploratory look at Web page use by a specific group of businesses within the tourism industry, tourist lodge operators. Other sub-sectors of this industry might also benefit from using websites, for example operators with events that occur once a year and need to be repeatedly promoted in order to attract a new clientele.

This exploratory study contains some inherent weaknesses. There may be confounds to the results of website traffic and emails caused by the initial size of the lodge client base. If a large lodge develops a website it is reasonable to assume it would have more financial resources to do so and would have more clients who are interested in the website. Future studies should control for size by recording some indicative variables such as the number of employees, the square footage of the buildings, and the number of rooms.

As a self-report a number of biases are inherent when requesting subjective data. Further development of objective measures and third party information sources would alleviate this concern.

Future studies might be more specific with respect to hypotheses and testing. Narrowing the number of tests is preferable. A large number of tests increase the risk of Type I error. An increase in sample size would increase power and reduce the risk of Type II error.

This initial study attempts to uncover some objective results from adopting a website; in the future it would be useful to examine the consumer perspective through decision processes and the actual effect viewing a website has on the decision to purchase a tourist lodge vacation. This might be captured in such variables as number and quality of pictures on a website, the amount and quality/informative aspects of narrative text, the currency of the site, and its loading rapidity. The goal is to shed more light on the question of what makes a successful website. It would also be useful to investigate, through standard consumer behavior models, what role is played by the Internet within the whole decision-making process of choosing, for example, a vacation destination, and how consumers obtain additional information. Other factors such as the reluctance of consumers to realize monetary transactions on line must also play a role.

The model proposed in this study is exploratory, but a number of relationships which bear further investigation have been revealed. Future research should refine this model and expand it to include a consumer perspective. In this way more can be learned about the characteristics of websites and what makes them useful/ attractive as a marketing communications medium. 


\section{Bibliography}

Beckman, M.D. and J.M. Rigby. 2003. Foundations of Marketing. Scarborough, ON: Nelson

Buhalis, D. and H. Main. 1996. "Information Technology in Small/Independent Welch and Agean Hotels," Proceedings of the Hospitality Information Technology Association Conference, Edinburgh HITA, London.

Cachon, J.C. and B. Cotton. 1997. The I.N.O.V.E. Project. Sudbury, ON: Laurentian Press.

Connolly, D.J., M.D. Olsen and R.G. Moore. 1998a. "The Internet and Travel: A Good Fit," Cornell Hotel and Restaurant Administration Quarterly 39, no. 4: 50.

- 1998b. "The Internet as a Distribution Channel," Comell Hotel and Restaurant Administration Quarterly 39, no. 4: 42.

Dotcom Survival Guide. 2000. Creative Good, Inc. New York, NY.

Hoffman, D.L. and T.P. Novak. 1996. "Marketing in Hypermedia Computer-mediated Environments: Conccptual Foundations," Journal of Marketing 60, no. 3: 50-68.

Lituchy, T.R. and A. Rail. 2000. "Bed and Breakfasts, Sinall Inns, and the Internet: The Impact of Technology on the Globalization of Small Businesses," Journal of International Marketing 8, no. 2: 6 .

Marcussen, C.H. 2003a. "Trends in European Intemet Distribution of Travel and Tourism Services," Centre for Regional and Tourism Research, Bornholm, Denmark.

- 2003b. Trends in the U.S. Online Travel Market-2000-2002. Centre for Regional and Tourism Research, Bornholm, Denmark.

Morgan, R.F. 1996. "An INTERNET Marketing Framework for the World Wide Web (WWW)," Journal of Marketing Management 12: 757-75.

Mougayar, W. 1998. Opening Digital Markets: Battle Plans and Business Strategies for Internet Commerce. New York: McGraw-Hill.

O'Connor, P. 1999. Electronic Information Distribution in Tourism and Hospitality. New York: CABI Publishing.

PhoCusWright Yearbook. 1999. Sherman, CT: PhoCusWright, Inc

PhoCusWright Yearbook. 2000. Sherman, CT: PhoCusWright, Inc.

Statistics Canada. 2001. 2001 Canadian Travel Survey, 2001 International Travel Survey.

- 2001. Beyond the Information Highway: Networked Canada.

Stergiou, S. and D. Airey. 2003. "Website Effectiveness: Assumptions, Problems and Potential," Tounism and Hospitality Research 4, no. 4: 355-66

Turban, E., J. Lee, D. King and H.M. Chung. 2000. Electronic Commerce: A Managerial Perspective. Upper Saddle River, NJ: Prentice Hall.

Van Doren, Doris C., D. Fechner and K. Green-Adelsberger. 2000. "Promotional Strategies on the World Wide Web," Joumal of Marketing Communications 6: 21-35.

Van Hoof, H.B. and T.E. Combrink. 1998. "U.S. Lodging Managers and the Internet," Cornell Hotel and Restaurant Administration Quarterly 39, no. 4

Veenhof, B., P. Neogi and B. van Tol. 2003. "High-speed on the Information Highway: Broadband in Canada," Statistics Canada, Science, Innovation and Electronic Information Division, Ottawa

\section{Acknowledgments}

The authors acknowledge and appreciate the support of CMA Ontario.

\section{Contact Information}

For further information on this article, contact Ron Mulholland or Jean Charles Cachon, Laurentian University, 935 Ramsey Lake Road, Sudbury, Ontario P3E 2C6

Telephone: (705) 6751151 ext. 2123 or 2126

Email: rmulholland@laurentian.ca jccachon@laurentian.ca 